\title{
Effects of adapted language materials in teaching listening on improving students' English listening skill
}

\section{Nguyen The Binh*}

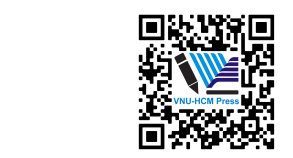

Use your smartphone to scan this QR code and download this article
Phan Rang - Thap Cham Department of Education and Training, Ninh Thuan Province, Vietnam

\section{Correspondence}

Nguyen The Binh, Phan Rang - Thap Cham Department of Education and Training, Ninh Thuan Province, Vietnam

Email: binhthe892@gmail.com

\section{History}

- Received: 4/4/2020

- Accepted: 16/12/2020

- Published: 28/12/2020

DOI : 10.32508/stdjssh.v4i4.619

\section{Check for updates}

\section{Copyright}

(.) VNU-HCM Press. This is an openaccess article distributed under the terms of the Creative Commons Attribution 4.0 International license.

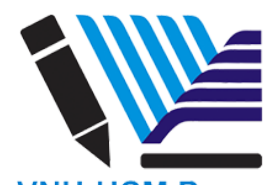

VNU-HCM Press

\begin{abstract}
So far the students of Le Hong Phong Junior High School, Phan Rang - Thap Cham City, Ninh Thuan province have been taught listening comprehension with textbook-based language materials which are too obsolete. Therefore, the students are often fed up with listening lessons; thus, their listening skill fails to improve after studying listening with textbooks for many years. Stimulated by this reality, the current study was carried out to investigate the effects of the adaptation of language materials in teaching listening on students' achievement of listening skill development. To obtain the above target, a conceptual framework of teaching listening with adapted language materials was developed. This framework was based on the theories of teaching listening and the implementation of language materials adaptation in listening skill instruction. Following the shaped conceptual framework, a training program with six listening lessons within the prescribed curriculum of "Tiếng Anh 8" by the MoET was conducted. The treatment lasted nearly four months from the middle of August 2018 to the end of November 2018 at Le Hong Phong Junior High School, Phan Rang - Thap Cham City, Ninh Thuan province. The results of the current study have shown that after the treatment of listening instruction with adapted language materials, students' achievement was proved to be significant in improving their listening skill. Also, teaching listening with adapted language materials got positive attitudes from the students. That is to say, adapted language materials were effective in improving students' listening skill development. Also, all the adapted listening texts and follow-up tasks highly met students' satisfaction. Accordingly, two major conclusions could be withdrawn from the findings that language materials adaptation was effective in (1) improving the students' listening skill, and (2) enhancing their interest in the listening lessons.
\end{abstract}

Key words: textbook-based language materials, adapted language materials, listening skill, teaching listening skill

\section{INTRODUCTION}

Regarding the current trend of language teaching in Vietnam, the primary aim of ELT is supposed to develop learner's communicative competence. Therefore, most textbooks by the MoET are designed based on training four skills: listening, speaking, reading, and writing. Of these skills, listening is the most significant but the most difficult for learners of all levels. Firstly, listening is the most important for a foreign language learner. We cannot communicate effectively without listening, and communication is the main way to get information from foreign sources. According to Doff (1998), listening is used far more than any other single language skill in normal daily life. We can expect to listen twice as much as we speak. Much of language input comes from listening, and if that channel is blocked, students will learn less new English ${ }^{1}$. Secondly, listening is the most difficult language skill for foreign language learners, especially for Vietnamese students because students only focus on pronunciation, not the main idea, and the teacher encourages them to do this although this is not a good approach (ibid.).

In reality of ELT in Vietnamese high schools, teaching the listening skill is problematic till now. It is found that students are often more and more bored to learn the listening skill during the years of studying English at school with current textbooks. This originates from the fact that most of the listening texts and follow-up tasks embraced in textbooks are too obsolete. Via his class observations and personal communications with practitioners and students during the years of teaching English, the researcher proves this. With teachers, they assert that the obsolete language materials in textbooks do not stimulate their interest in dealing with their teaching process. However, teachers are quite satisfied with these language materials because they are easy and available to apply; they do not require any endeavor from teachers. But for students, most of them are depressed when talking about listening lessons. They state that it is not an enjoyable job to 
tackle with the listening texts and the follow-up tasks because all are not fresh ones. All are often easily dealt with in a wink thanks to either the guidebooks or the previous graders.

Relating to this aspect of language teaching, various problems with materials have been addressed by several researchers. O’Neill (1982) suggests that textbooks can only provide props and a framework for classroom teaching ${ }^{2}$. Swales (1980) contends that any given course-book will be incapable of catering for the diversity of needs that exists in most language classrooms ${ }^{3}$. The matters mentioned here are that teachers should see textbooks as their servants instead of masters; as a resource or an 'ideas bank' which can stimulate teachers' creative potential $^{4}$ (Cunnningsworth, 1984). Adapting their materials allows them to achieve more compatibility and fitness between the textbook and the teaching environment, and maximize the value of the book for the benefit of their particular learners and for the most effective teaching outcomes to achieve (ibid.).

In a word, based on the reviewed background and the mentioned problem, textbook-based listening lessons are subject to adaptation when they are used in classrooms so that the English listening teaching will be more effective and interesting. Thus, the research is conducted to help students get improved in their English listening skill.

The current study aims at (1) to clarify the effects of adapted listening texts and follow-up tasks on students' improvement on listening skill, and (2) to ascertain students' attitudes towards listening lessons with adapted language materials. To get the target, the following research questions are addressed: (1) Do the adapted language materials affect students' achievement of the listening skill? (2) What are students' attitudes towards the listening lessons with adapted language materials?

\section{METHODOLOGY}

For this study, the students of two classes $\left(8^{1}\right.$ and $\left.8^{2}\right)$ were selected to take part in the experiment; one is the control group, the other is the experimental one. This choice relied on students' equivalence in English capability at the beginning of the treatment and of course, it was enabled by the school administrators. At the beginning of the experiment, the two groups were somehow equivalent in some aspects (learning environment, learning conditions, learning chance, and learning aptitude). They were all at the same age and had learned English as one of the compulsory subjects for five years at school. Their English proficiency at the elementary level is supposed to be equal. A summary of participants' characteristics is displayed in Table 1.

As shown in Table 1, both groups had an approximate total number of students: thirty-seven and thirty-five. The number of females between the two groups was not far differential: sixteen and eighteen in the experimental one. The English capability between the two groups was not considerably different. Just assume that the final scores on the English subject of grade 7 were valid, they were used for establishing equivalence in English proficiency between the two groups at the time before the treatment.

The research design aimed at examining whether or not an intervention of adapted language materials applied to the listening teaching over junior high school students' progress in listening skill as well as their attitudes towards instructed listening lessons would be effective. For this target, the study followed a quasi-experimental study design in the form of posttests with a control group that is succinctly displayed in Figure 1. Additionally, another dependent variable of students' attitudes towards instructed listening lessons with adapted language materials was measured within the experimental group.

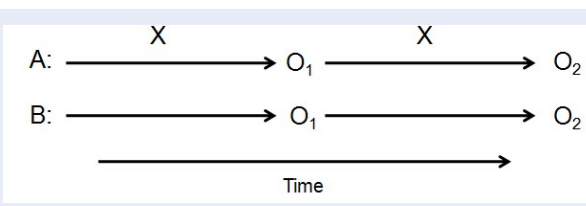

Figure 1: Design of the study ${ }^{a}$

${ }^{a}$ Note. $\mathrm{A}=$ Experimental group; $\mathrm{B}=\mathrm{Control}$ group; $\mathrm{X}=$ Treatment; $\mathrm{O}_{1}=$ Post-test $1 ; \mathrm{O}_{2}=$ Post-test2

It took almost four months (from the middle of August to the end of November 2018) to do the research, including the administrations of tests and questionnaires. Six listening lessons embraced in the first-term curriculum of "Tiếng Anh 8 " ${ }^{5}$ were taken into the treatment in succession. The full study procedure is going to be chronologically described as two stages of pre- and training phases.

To begin the treatment, all preparations were carefully made. The researcher took the two major concerns into careful consideration. These were (1) what language materials from the course-books to be used for replacing and rewriting the obsolete language materials in the textbook; and (2) how to adapt and apply the adapted language materials so that they met both the six textbook-based listening topics and the students' satisfaction. 
Table 1: Summary of participants' characteristics at the beginning of the treatment

\begin{tabular}{|c|c|c|c|c|c|c|c|c|}
\hline \multirow[t]{2}{*}{ Group } & \multirow[t]{2}{*}{$\mathrm{N}$} & \multicolumn{2}{|c|}{ Gender } & \multicolumn{5}{|c|}{ Final scores on English subject at the end of grade 7} \\
\hline & & Male & Female & $<3.5$ & $3.5-4.9$ & $5.0-6.4$ & $6.5-7.9$ & $8.0-10$ \\
\hline \multirow[t]{2}{*}{ Control $\left(8^{1}\right)$} & 37 & 21 & 16 & 3 & 5 & 12 & 12 & 5 \\
\hline & & $56.8 \%$ & $43.2 \%$ & $8.1 \%$ & $13.5 \%$ & $32.5 \%$ & $32.5 \%$ & $13.5 \%$ \\
\hline \multirow[t]{2}{*}{ Experimental $\left(8^{2}\right)$} & 35 & 17 & 18 & 4 & 4 & 8 & 13 & 6 \\
\hline & & $48.6 \%$ & $51.4 \%$ & $11.4 \%$ & $11.4 \%$ & $34.3 \%$ & $37.1 \%$ & $18.8 \%$ \\
\hline
\end{tabular}

First, dealing with the job of materials adaptation, the eight options (i.e. omission, addition, reduction, extension, rewriting/modification, replacement, reordering, branching $)^{6}$ suggested by Maley (2010, as cited in Tomlinson, 1998) were taken into account. Of these, rewriting and replacement were the best choices because they can meet the actual situation of the current study that the language materials in the curriculum-prescribed textbooks are too obsolete. These ways, teacher may rewrite materials, especially exercise materials, to make them more appropriate, more "communicative", more demanding, more accessible to their students, etc.; or replace text or exercise materials which are considered inadequate for whatever reason by more suitable materials culled from other resource materials.

Next, some course-books that were commonly used as official language manuals in many language centers were taken into careful consideration for adapted listening texts and follow-up tasks. Typically, Connect $(2001)^{7}$ and New Interchange $(2005)^{8}$ were the ones that got high appreciation from the researcher himself and many of his practitioners for their communicative and authentic language materials.

Six listening lessons in the prescribed curriculum embracing six topics (i.e. my friends, making arrangements, at home, our past, study habits, and the young pioneers club) were then planned for the two-group training practice afterward. Of course, the six listening lessons were deployed with adapted materials and follow-up tasks. All six listening-lesson plans were conventionally designed in the same model of Pre While - Post relied on the framework for listening lesson plans ${ }^{9}$ as recommended by Richards (1999). This may be summarized as can be seen in Figure 2 .

In about planning of listening-skill lessons, the training process observed the three vital principles ${ }^{10}$ illustrated by Gower, Phillips, and Walters (2005): (1) Preparation is vital, (2) Students should be encouraged to respond to the content of listening, not just to the language, and (3) Different listening stages demand different listening tasks.
Finally, after six listening-skill lessons were planned, the student questionnaire was designed for the experimental group. Post-test 1 and post-test 2 papers were at once taken into scoring and statistics process. Naturally, the scores of listening sections included in the whole paper-tests were converted into a scale of tenpoints for easy statistics later.

The procedure of training took place from week 1 to week 14 of the school year 2018-2019 including distributions of two tests and student questionnaires. One week right after the final treatment, the experimental group has distributed the questionnaires so that students' assessment of the instructed listening lessons was investigated. They were asked to complete and hand in the questionnaire on the spot within ten minutes. Concurrently, two test-papers of the two groups were gathered, marked, and analyzed for the research findings afterward. The whole procedure of the study is briefly described in Table 2 .

As mentioned above, two instruments (i.e. tests and student questionnaires) were utilized to collect data. The questionnaire targeted at measuring students' attitudes over listening lessons instructed with adapted language materials. The final scores on the English subject of grade 7 were used to examine students' equivalence in English language capacity. Post-test1 and post-test 2 aimed at measuring students' achievement of the listening skill after a certain period of treatment.

For the current questionnaire, all the questions were designed in an entirely close-ended form to get specific aspects of the issues. All the close-ended questions followed the technique of a five-point Likert scale from 1 (strongly disagree) to 5 (strongly agree). The respondents were provided with ready-made responses to choose; they hence were not required to produce any free writing. As mentioned above, the participants were asked to complete the questionnaire on the spot within ten minutes. Thirty-five Vietnamese copies were administrated to the participants on 16th November 2018, one week after they had finished the final treatment. The questionnaire distribution was done in the class meeting at the end of the 


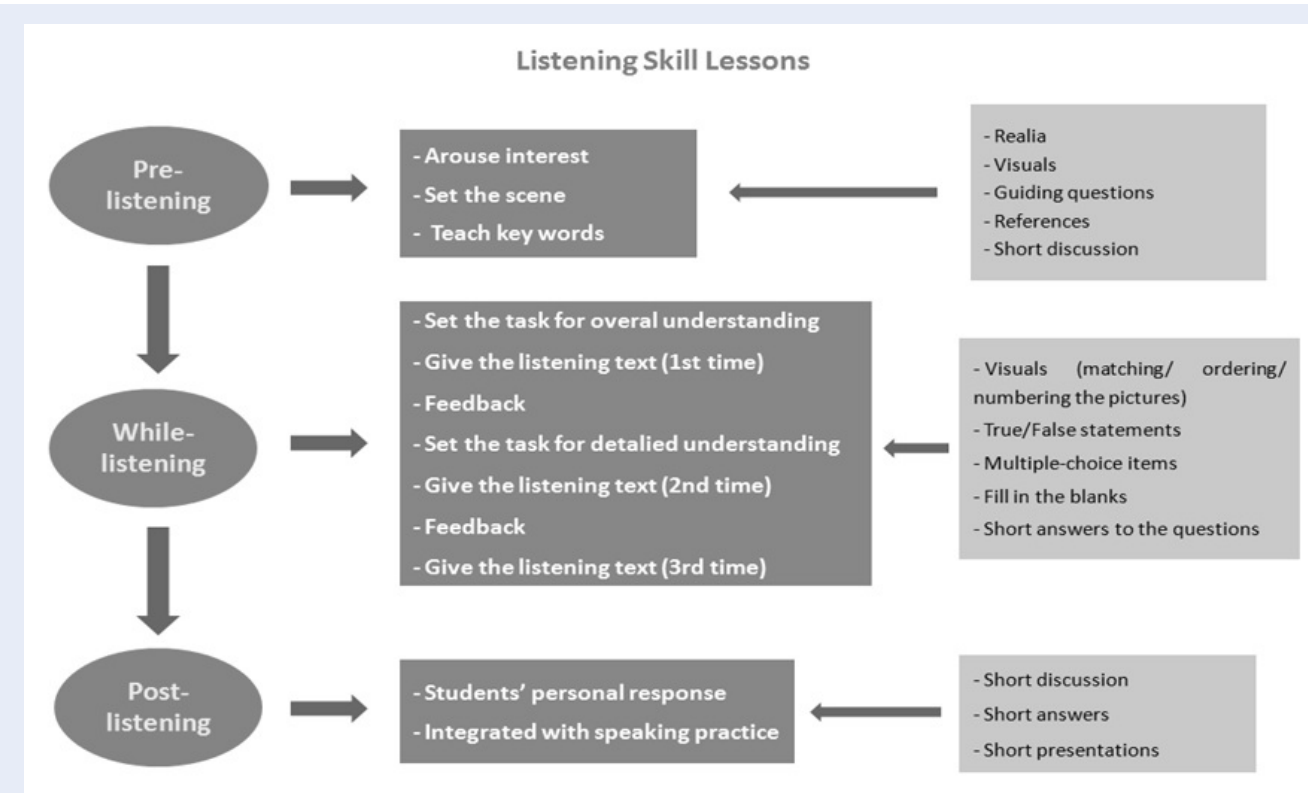

Figure 2: Framework of a listening lesson

Table 2: Schedule of study procedure

\begin{tabular}{|c|c|c|}
\hline Week & Jobs & Target date \\
\hline $\begin{array}{l}1 \\
20 / 8-25 / 8 / 2018\end{array}$ & Treatment 1: My friends & $21 / 8 / 2018$ \\
\hline $\begin{array}{l}4 \\
10 / 9-15 / 9 / 2018\end{array}$ & Treatment 2: Making arrangements & $11 / 9 / 2018$ \\
\hline $\begin{array}{l}6 \\
23 / 9-29 / 9 / 2018\end{array}$ & Treatment 3: At home & $24 / 9 / 2018$ \\
\hline $\begin{array}{l}7 \\
01 / 10-05 / 10 / 2018\end{array}$ & $1^{s t}$ Periodical Test (Post-test 1$)$ & $04 / 10 / 2018$ \\
\hline $\begin{array}{l}8 \\
08 / 10-13 / 10 / 2018\end{array}$ & Treatment 4: Our past & $11 / 10 / 2018$ \\
\hline $\begin{array}{l}10 \\
22 / 10-27 / 10 / 2018\end{array}$ & Treatment 5: Study habits & $25 / 10 / 2018$ \\
\hline $\begin{array}{l}12 \\
05 / 11-10 / 11 / 2018\end{array}$ & Treatment 6: The young pioneers club & $08 / 11 / 2018$ \\
\hline $\begin{array}{l}13 \\
12 / 11-17 / 11 / 2018\end{array}$ & Questionnaire distribution & $17 / 11 / 2018$ \\
\hline $\begin{array}{l}14 \\
19 / 11-24 / 11 / 2018\end{array}$ & $2^{\text {nd }}$ Periodical Test (Post-test2) & $22 / 11 / 2018$ \\
\hline
\end{tabular}


week with the permission of the form-teacher, so it did not interfere with any lessons. Favorably, the exact number of thirty-five completed copies was handed in.

As usual, the questionnaire included two separate sections. The sub-section focused on personal information about the treatment participants. This section consisted of four items aiming at discovering whether or not there were any relationships between students' achievement and their background. Such information as ages, genders, length of English language learning, and final scores on English subject in the previous school-year was embraced in this section. The main section aimed at collecting data on the students' attitudes over listening lessons instructed with adapted language materials. This section was designed with fifteen items revolving students' evaluation of two main themes: listening texts and follow-up task design. The design of such questionnaire items was based on the principles of materials adaptation ${ }^{11}$ recommended by Grant (1987); specifically, making dialogues communicative, making learning activities relevant and purposeful, meeting learners' needs both external and psychological, using models of real, authentic language, etc...

Regarding the current study, tests were used to measure the subjects' English listening. The results were thence investigated to assess the effectiveness of the treatment. For this purpose, there were two administrated tests (i.e. post-test 1 and post-test2) in forms of paper-tests for both groups. These tests of listening were just embraced in the periodical tests based on the curriculum framework by the MoET.

In detail, post-test 1 was administrated to collect data on the students' competence in listening skill development after three treatments. It was designed in the form of filling in the telephone message with missing information. It included five items and made up $20 \%$ of the total score in the first periodical paper-test. Similarly, the post-test 2 was distributed to collect data on the students' capability for the listening skill after the whole training process. It was developed in two forms: true-false statements and question-answers. It consisted of ten items and made up 25\% of the total score in the second periodical paper-test.

Concerning paper scoring, one rater from the English language staff was invited for paper marking. She had been clearly explained the purpose, the significance of test data beforehand, and well trained in test scoring. She thus willingly gave help; and the expected results were later returned to the researcher for the coming analysis.

\section{DATA ANALYSIS AND FINDINGS DISCUSSION}

\section{Do the adapted language materials af- fect students' achievement of the listening skill?}

To respond to this research question, the descriptive statistics data that stemmed from the two tests were calculated and analyzed. The measurement of the mean (M) was taken into analysis to find out the effect of the treatment on students' achievement of the listening skill. The data analysis and finding discussion is going to be illustrated along the two periods of time: post-test 1 and post-test 2 .

The results of the post-test 1 of the two groups, as in Table 3, shows that the experimental group got a bit higher scores than the control one $(M=5.35$ vs. $M=$ 5.24); however, there was a statistically insignificant difference between two mean scores $(p=.66)$. Hence, it was no doubt to affirm that two groups were equivalent in listening skill after three treatments. A possible explanation for the above finding might be that three treatments within six weeks are not enough for the evident improvement.

As in Table 4, the results of post-test 2 of two groups reveals that the treatment group got strongly higher scores than the other one ( $M=7.00$ vs. $M=5.97$ ), and the disparity between two mean scores was statistically significant $(p=.04)$. Thus, the experimental group surpassed the control one in listening skill after six treatments lasting nearly fourteen weeks from week 1 to week 14 was completely safe to assert.

Thanks to the aid of the Pair samples t-test, the collected data were calculated and summarized as in Table 5. This will give information about the difference in results between post-test 1 and post-test 2 within two groups.

The data in Table 5 indicates that, on average, two groups achieved higher scores in post-test 2 than in post-test1. Specifically, the mean score of post-test2 was 5.97 compared with 5.24 of post-test 1 for the control; the mean score of post-test 2 was 7.00 in comparison with 5.35 of post-test 1 and with the experimental one. Nevertheless, the variance was significantly different at the $p$-values of .02 levels for the experimental group; while, the difference was insignificant for the control $(p=0.26)$. This shows that teaching listening with adapted materials was effective in improving the students' listening skill.

In short, the study found that adapted language materials were effective in improving students' listening development. This was owing to such factors as the sensible adaptation of listening texts and the flexible integration of various tasks within listening lessons. 
Table 3: Summary of post-test 1 results

\begin{tabular}{llllll}
\hline Group & $\mathrm{N}$ & \multicolumn{2}{l}{ Post-test1 scores } & & $\mathrm{p}$ \\
& & $\mathrm{M}$ & $\mathrm{S} . \mathrm{D}$. & $\mathrm{t}$ & .66 \\
Control $\left(8^{1}\right)$ & 37 & 5.24 & 0.94 & -.438 & \\
Experimental $\left(8^{2}\right)$ & 35 & 5.35 & 1.24 & & \\
\hline
\end{tabular}

Table 4: Summary of post-test2 results

\begin{tabular}{llllll}
\hline Group & $\mathrm{N}$ & \multicolumn{2}{l}{ Post-test2 scores } & & \\
& & $\mathrm{M}$ & S.D. & $\mathrm{t}$ & $\mathrm{p}$ \\
Control $\left(8^{1}\right)$ & 37 & 5.97 & 1.28 & -3.083 & .04 \\
Experimental $\left(8^{2}\right)$ & 35 & 7.00 & 1.36 & & \\
\hline
\end{tabular}

Table 5: Summary of post-test 1 and post-test 2 results

\begin{tabular}{lllllllllll}
\hline Test & \multicolumn{3}{c}{ Control group (81) } & \multicolumn{7}{c}{ Experimental group (82) } \\
& $\mathrm{N}$ & $\mathrm{M}$ & $\mathrm{S} . \mathrm{D}$. & $\mathrm{t}$ & $\mathrm{p}$ & $\mathrm{N}$ & $\mathrm{M}$ & S.D. & $\mathrm{t}$ & $\mathrm{p}$ \\
Post-test1 & 37 & 5.24 & 0.89 & -3.4121 & .26 & 35 & 5.35 & 1.20 & -30.453 & .02 \\
Post-test2 & 37 & 5.97 & 1.34 & & & 35 & 7.00 & 1.02 & & \\
\hline
\end{tabular}

What are students' attitudes towards listening lessons with adapted language materials?

In response to this research question, the type of descriptive statistics data from the questionnaire was analyzed. The advanced types of measurement: mean (M) were used to analyze the results. This section provides information related to students' attitudes over listening lessons instructed with adapted language materials in terms of the content of listening texts and task design applied to the whole training procedure. As presented, after the treatment, thirty-five copies of the questionnaire were administrated to the experimental group to investigate students' attitudes towards the instructed listening lessons. The questionnaire included fifteen close-ended questions. Interestingly, within ten minutes, $100 \%$ of participants completed and handed in the questionnaire on the spot. The collected data were then calculated and interpreted in the measurement of the mean. For more convenience in discussing, the evaluation was rated on a narrowed three-bank scale: low evaluation (1 $2.8)$, medium evaluation ( $2.9-3.6)$, and high evaluation $(3.7-5.0)$. The data analysis is going to be illustrated in both prose and tables, and organized along with two themes: adapted listening texts and followup tasks.

Involved in the theme of adapted listening texts were three items (items $1-3$ ), which scrutinized students' assessment of the adapted texts. The results of this investigation were summarized in Table 6 .

Table 6 shows that most of the respondents confirmed that the content of adapted texts did meet their needs $(\mathrm{M}=4.09)$; and it was vivid and communicative ( $\mathrm{M}$ $=4.02)$. Furthermore, the language content of the listening texts was real and authentic $(M=4.15)$. All these three mean scores were in the range of high evaluation $(3.7-5.0)$; that is to say, the students' assessment of the language content was quite positive.

Involved in the pre-listening stage were five items (items $4-8$ ), which scrutinized students' assessment of pre-listening task design. The results of this investigation were summarized in Table 7.

As revealed in Table 7, the means ranging from 4.00 to 4.19 offer positive results. The task design introduced at the beginning of each lesson is found interesting by most of the participants $(M=4.19)$. They were facilitated in comprehending new lessons $(\mathrm{M}=$ 4.16) helped to build confidence by the tasks. They almost agreed that the tasks were developed at a reasonable level for them to complete $(\mathrm{M}=4.00)$. This stage of pre-listening, at their comments, took no much time $(\mathrm{M}=4.05)$. On the whole, all these five mean scores within this sub-theme were in the range of high evaluation $(3.7-5.0)$; that means task design in the pre-listening stage got a positive assessment from students.

Embraced in while and post-listening stages were seven items (item 9 - 15) which examined students' 
Table 6: Students' attitudes towards listening texts

\begin{tabular}{lll}
\hline Items & Content & M \\
1 & The content of the adapted texts meet my needs. & 4.09 \\
2 & The content of the adapted texts are vivid and communicative. & 4.02 \\
3 & The language content of the adapted texts is real and authentic. & 4.15 \\
\hline
\end{tabular}

Table 7: Students' attitudes towards task design in pre-listening stage

\begin{tabular}{lll}
\hline Items & Content & M \\
4 & The pre-listening tasks generate my interest. & 4.19 \\
5 & The pre-listening tasks help to build confidence. & 4.11 \\
6 & The pre-listening tasks facilitate comprehension. & 4.16 \\
7 & The pre-listening tasks are designed at reasonable level for me to deal with. & 4.00 \\
8 & The phase of pre-listening is not time-consuming. & 4.05 \\
\hline
\end{tabular}

evaluation of features of the follow-up tasks applied to these stages. These are variety, enjoyment, challenge, pressure putting, the demand for a response, reaction to the text content, and language analysis. The results of this examination were summarized in Table 8.

The means ranging between 4.02 and 4.33 as in Table 8 indicate that most of the students showed positive comments to the seven items related to these stages of while and post-listening. Nearly all had a strong agreement that the tasks utilized in these stages were varied $(\mathrm{M}=4.24)$. With most of them, the tasks in these stages were enjoyable $(\mathrm{M}=4.16)$ and challenging enough $(M=4.03)$. A majority of participants showed their approval to the view that the tasks did not put them under too much pressure (4.02) and demand too much of a response (4.33). Two final mean scores $(M=4.16$ and $M=4.09)$ proved that most of the participants realized the great benefits - reaction to the content and language analysis these tasks required and brought about. In short, all seven high-evaluated mean scores $(3.7-5.0)$ within this sub-theme show a great concurrence of most of the respondents over the employed listening tasks.

With the above results, it may be that the participants benefited from the adapted language materials utilized in the training procedure. All helped involve the participants' interest in the lessons and maintain their learning motivation from the start to the end of the lessons.

Briefly, most of the participants supported the trial method with more positive than a negative assessment of the adapted language materials applied to listening-skill lessons is found from the present study. All the adapted listening texts and follow-up tasks highly met students' satisfaction. They were involved in all the activities during the three stages of the lesson procedure.

\section{CONCLUSION AND RECOMMENDATION}

The findings discussed in the previous part show that, in general, the adapted materials indeed helped students improve their listening. Also, this implementation appealed the students' interest in the listening lessons. Specifically, the first finding reveals that being instructed listening with adapted materials, the students achieved better outcomes in listening comprehension. This was demonstrated by the results that the students who were taught listening with adapted materials got higher scores after the whole treatment than before. Furthermore, the results on the listening tests of the students who were taught listening with adapted materials far outweighed those who were taught listening with original textbook-based listening texts and follow-up tasks. This finding reveals that adapted listening texts and follow-up tasks did benefit students in improving the listening skill; hence, it well deserves application in teaching listening within the actual situation of Le Hong Phong Junior High School.

The second finding shows that, in addition to the students' improvement in listening, the adaptation of language materials did get a positive attitude from the students. The findings derived from the questionnaires show the participants' high evaluation of the instructed listening lessons. These findings confirm that besides the effect that the adapted listening texts and follow-up tasks bring about in terms of developing students' listening skill, they catch the students' 
Table 8: Students' attitudes towards task design in while and post-listening stages

\begin{tabular}{lll}
\hline Items & Content & M \\
9 & The while and post-listening tasks are varied. & 4.24 \\
10 & The while and post-listening tasks are enjoyable. & 4.16 \\
11 & The while and post-listening tasks are challenging enough to perform. & 4.03 \\
12 & The while and post-listening tasks do not put me under too much pressure. & 4.02 \\
13 & The while and post-listening tasks do not demand too much of a response. & 4.33 \\
14 & The while and post-listening tasks help me to react to the content of the text. & 4.16 \\
15 & $\begin{array}{l}\text { The while and post-listening tasks help to analyze of the linguistic features used to express } \\
\text { the content. }\end{array}$ & 4.09 \\
\hline
\end{tabular}

learning interest. This enhances the constructive view on the adapted listening materials within the teachers of English in Le Hong Phong Junior High School, and fosters them to apply it thoroughly to boost their professional competence.

Despite the certain success of the study, its several important limitations due to practical constraints need to be admitted. First, the number of six listening lessons taken into the treatment was rather limited. The results would have been more convincing the study had included all curricular listening lessons of the whole school year. Second, the listening tests did not cover the whole paper-tests, just count up onefive or one-four of the paper, so students' listening capacity could not be comprehensively indicated from the collected data. Finally, it was beyond the scope of the study that just 8th graders, not all students of the school, were involved to investigate the issue. Besides, the study was conducted on a small subject scale - Le Hong Phong Junior High School, which is a highquality central school in the city; hence, the findings are not intended to be generalized.

Overall, it is hoped that this study will bring an innovation to English listening teaching in junior high schools, or at least in Le Hong Phong Junior High school. However, to get a more comprehensive understanding of this application of adapted language materials in the listening teaching, more research on this topic needs to be undertaken and takes these recommendations into serious account. First, further experimental investigations are needed conducting on such a large scale as the whole grade or even the whole school within a longer-term, a whole school-year for instance. Second, it may be more interesting to assess the effects of language materials adaptation in listening training if more complex listening lessons are taken into treatment; and the achievement tests include more numerous target items, a delayed post-test is administrated. Finally, further research might explore the effects of the application of language materials adaptation in the area of teaching reading comprehension, or even investigate these in the field of teaching writing.

\section{ACKNOWLEDGEMENT}

The author would like to acknowledge all of the people without whom this paper would not have been at all possible. First, his special thanks are reserved for Ho Chi Minh City Open University Library where the author has been offered a lot of documents for reference. Then, his gratitude is expressed to the administrators of Le Hong Phong Junior High School, Phan Rang - Thap Cham City, Ninh Thuan province, who were always willing to support and facilitate him in his conducting the research.

\section{ABBREVIATION}

ELT: English Language Teaching

MoET: Ministry of Education and Training

\section{CONFLICT OF INTEREST}

The manuscript has no conflict of interest.

\section{AUTHORS' CONTRIBUTION}

Nguyen The Binh has done all the research work ofthe article as a sole author

\section{CONTRIBUTION STATEMENT}

The current study was carried out to investigate the effects of the adaptation of language materials in teaching listening on students' achievement of listening skill development. To obtain the above target, a conceptual framework of teaching listening with adapted language materials was developed. This framework was based on the theories of teaching listening and the implementation of language materials adaptation 
in listening skill instruction. Following the shaped conceptual framework, a training program with six listening lessons within the prescribed curriculum of "Tiếng Anh 8" by the MoET was conducted. The treatment lasted nearly four months from the middle of August 2018 to the end of November 2018 at Le Hong Phong Junior High School, Phan Rang Thap Cham City, Ninh Thuan province. A quasiexperimental study design including post-test administrations with a control group was applied. Seventytwo students of grade 8 who were located in two classes $8^{1}$ and $8^{2}$ were chosen based on their equivalence in English capability to take part in the experiment. The quantitative data were collected via two instruments: tests and student questionnaire. These statistically descriptive data were then analyzed and interpreted for the research findings. The results of the current study have shown that after the treatment of listening instruction with adapted language materials, students' achievement was proved to be significant in improving their listening skill. Also, teaching listening with adapted language materials got positive attitudes from the students. That is to say, adapted language materials were effective in improving students' listening skill development. Also, all the adapted listening texts and follow-up tasks highly met stu- dents' satisfaction. Accordingly, two major conclusions could be withdrawn from the findings that language materials adaptation was effective in (1) improving the students' listening skill, and (2) enhancing their interest in the listening lessons.

\section{REFERENCES}

1. Doff A. Teach English: A Training Course for Teachers (Trainer's Handbook). Cambridge: Cambridge University Press. 1988;

2. O'Neill R. Why use textbooks? ELTJ. 1982. 36(2):104-11 ;Available from: https://doi.org/10.1093/elt/36.2.104.

3. Swales J. ESP: The textbook problem. ESPJ. 1980. 1(1):11-23 ;Available from: https://doi.org/10.1016/0272-2380(80)900062.

4. Cunningsworth A. Evaluating and Selecting EFL Teaching Materials. London: Heinemann. 1984;.

5. Tomlinson B. Materials development. In R. Carter and D. Nunan (eds). The Cambridge Guide to Teaching English to Speakers of Other Languages. Cambridge: Cambridge University Press. 1998;.

6. Bộ Giáo dục và Đào tạo. Tiếng Anh 8 . Hà Nội: Nhà xuất bản Giáo dục Việt Nam. 2012;.

7. Richards JC. Connect. Cambridge: Cambridge University Press. 2001;

8. Richards JC. New Interchange. Cambridge: Cambridge University Press. 2005;

9. Richards JC. Teaching Listening and Speaking. Cambridge: Cambridge University Press. 1999;.

10. Gower R, Phillips D, Walters S. Teaching Practice. Oxford: Macmillan Education. 2005;p. 138-139.

11. Grant F. Language Materials Adaptation. [Online]. 1987. [cited 2018 Aug 15];[15-8 screens];Available from: http://www. languages.ait.ac.th/hanoi_proceedings/canh.htm. 


\section{Hiệu quả của ngữ liệu phóng tác trong hoạt động dạy kỹ năng nghe đối với việc cải thiện kỹ năng nghe tiếng Anh của học sinh}

\section{Nguyễn Thế Bình*}

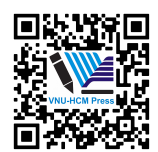

Use your smartphone to scan this QR code and download this article

\section{TÓM TẮT}

Cho đến nay, học sinh Trường trung học cơ sở Lê Hồng Phong, thành phố Phan Rang - Tháp Chàm, tỉnh Ninh Thuận được dạy kỹ năng nghe hiểu với ngữ liệu quá cũ trong sách giáo khoa. Do vậy, học sinh thường không hứng thú với các bài học nghe, và vì thế kỹ năng nghe không cải thiện sau nhiều năm học nghe với sách giáo khoa. Từ thực tế này, tác giả thực hiện nghiên cứu nhằm làm rõ các tác động của việc sử dụng ngữ liệu phóng tác trong việc dạy kỹ năng nghe đối với việc phát triển kỹ năng nghe cho học sinh. Để đạt mục đích trên, tác giả thiết kế khung chương trình dạy kỹ năng nghe dựa trên ngữ liệu phóng tác. Khung chương trình này căn cứ trên các lý thuyết về dạy kỹ năng nghe và áp dụng ngữ liệu phóng tác trong dạy kỹ năng nghe. Dựa theo khung chương trình, tác giả thực nghiệm 6 bài học nghe theo quy định trong chương trình "Tiếng Anh 8" của Bộ Giáo dục và Đào tạo. Thực nghiệm kéo dài gần 4 tháng từ giữa tháng 8 năm 2018 đến cuối tháng 11 năm 2018 tại Trường trung học cơ sở Lê Hồng Phong, thành phố Phan Rang - Tháp Chàm, tỉnh Ninh Thuận. Kết quả của nghiên cứu chỉ ra rằng sau khi thể nghiệm dạy kỹ năng nghe trên cơ sở ngữ liệu phóng tác, kỹ năng nghe của học sinh có cải thiện. Ngoài ra, việc dạy kỹ năng nghe với ngữ liệu phóng tác nhận được thái độ tích cực từ phía học sinh. Điều đó có nghĩa là ngữ liệu phóng tác có hiệu quả trong việc cải thiện kỹ năng nghe của học sinh. Đồng thời, ngũ liệu phóng tác của những bài học nghe và bài tập đi kèm đáp ứng sự hài lòng của học sinh. Từ đó, tác giả nêu ra hai kết luận cơ bản rằng việc sử dụng ngữ liệu phóng tác có hiệu quả trong việc (1) cải thiện kỹ năng nghe của học sinh và (2) tăng cường hứng thú của học sinh đối với các bài học nghe.

Từ khoá: ngữ liệu sách giáo khoa, ngữ liệu phóng tác, kỹ năng nghe, dạy kỹ năng nghe
Phòng Giáo duc và Đào tạo thành phố Phan Rang - Tháp Chàm, tỉnh Ninh Thuận, Việt Nam

\section{Liên hệ}

Nguyễn Thế Bình, Phòng Giáo dục và Đào tạo thành phố Phan Rang - Tháp Chàm, tỉnh Ninh Thuận, Việt Nam

Email: binhthe892@gmail.com

Lịch sử

- Ngày nhận: 4/4/2020

- Ngày chấp nhận: 16/12/2020

- Ngày đăng: 28/12/2020

DOI : 10.32508/stdjssh.v4i4.619

\section{Check for updates}

\section{Bản quyền}

๑ Đ ĐHQG Tp.HCM. Đây là bài báo công bố mở được phát hành theo các điều khoản của the Creative Commons Attribution 4.0 International license.

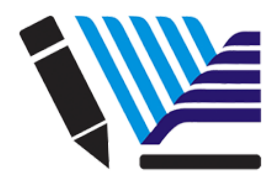

VNU-HCM Press
Trích dẫn bài báo này: Bình N T. Hiệu quả của ngữ liệu phóng tác trong hoạt động dạy kỹ năng nghe đối với việc cải thiện kỹ năng nghe tiếng Anh của học sinh. Sci. Tech. Dev. J. - Soc. Sci. Hum.; 4(4):654-663. 